\title{
THE ASPECTS AND BENEFITS OF THE ACTIVITY OF THE RURAL DEVELOPMENT MEASURE AGRI-ENVIRONMENTAL PROTECTION
}

\begin{abstract}
Vilma KRIAUČIŪNAITĖ-NEKLEJONOVIENĖ, Departament of Civil Engineering, Faculty of Civil Engineering and Architecture, Technologies, Kaunas University of Technology, Studentu str. 48, Kaunas LT-51367, Lithuania / Institute of Land Use Planning and Geomatics, Water and Land Management faculty, Aleksandras Stulginskis University, Lithuania. Universiteto str. 10, LT - 53361 Akademija, Kaunas reg., vilma.kriauciunaite@ktu.lt (corresponding author)

Vaiva STRAVINSKIENÉ, Institute of Land Use Planning and Geomatics, Water and Land Management faculty, Aleksandras Stulginskis University, Universiteto str. 10, LT-53361 Akademija, Kaunas reg. Lithuania. vaiva.stravinskiene@asu.lt

Rimanta CIBULSKAITE், Institute of Land Use Planning and Geomatics, Water and Land Management faculty, Aleksandras Stulginskis University, Universiteto str. 10, LT-53361 Akademija, Kaunas reg., Lithuania. cibulskaite.rimanta@gmail.com

Donatas REKUS, Departament of Civil Engineering, Faculty of Civil Engineering and Architecture, Technologies Kaunas University of technology, Studentu str. 48, Kaunas LT-51367, / Institute of Land Use Planning and Geomatics, Water and Land Management faculty, Aleksandras Stulginskis University, Universiteto g. 10, LT-53361 Akademija, Kauno reg., Lithuania. donatas.rekus@ktu.lt

It is planned to ensure the balanced development of the country's territory, creating and maintaining a healthy and harmonious human habitat and natural elements of the countryside and ensuring overall ecological stability by means of the agri-environmental protection activity measures RDP. As part of the EU's rural development policy, the tool for improving agri-environmental and climatic conditions has been continuously improved. The paper analyzes the differences between the 2007 -2013 RDP measure „Agri-environmental payments” and 2014-2020 RDP measure "Agrienvironment and climate". Comparison of the 4 directions of the 2007-2013 and 2014-2020 RDP measure "Agrienvironment and climate" according to the individual criteria for each direction indicate that the program rules are adjusted in a beneficial direction for both parties in close cooperation between the responsible authorities and the beneficiaries. In 2007-2013 it has been established that RDP measure "Agri-environmental payments" covered a much wider range of directions, and in 2014-2020, the RDP measure "Agri-environment and climate" had a slightly narrower range of directions, but more specific and clearer rules. However, the desired results can not be achieved. The greatest benefit of the measure is the improved biodiversity of the country. The main driving force for agri-environmental measures is financial support.
\end{abstract}

Keywords: rural development land use project, RDP, agri-environmental protection, climate, payments, measure, program, direction.

\section{INTRODUCTION}

Agriculture is changing our environment - over the past several years Europe has seen very strong and significant changes in agricultural land's biodiversity. The result is that all agricultural production should be produced by matching the country's ecological status and economy (Mouysset et al., 2011). Cooper (2009) describes agri-environment as a very broad area that includes environmental benefits, landscape improvement, water conservation, protection of biodiversity, climate change, air quality improvement, suppression of floods and severe fires. It also has a great social benefit, which includes food safety and quality, health, rural vitality and animal welfare. According to Whittingham (2007), agrienvironmental policy is intended, at least in part, to increase the biodiversity level of agricultural land, improve water quality, preserve the countryside, and restore the damage to nature already caused.

The European Union's rural development policy helps to solve the various economic, environmental and social challenges of the 21 st century in rural areas. One of the priorities of the Rural Development Program (RDP) is the growing competitiveness of the Lithuanian agriculture, forestry and food sector. After Lithuania's formal accession to the EU (from May 1, 2004), favorable conditions for the stable development of Lithuanian agriculture and rural development were created. According to P. Mierauskas (2012), agri-environmental programs have been relatively widespread and the variety of programs varies from country to country. In Lithuania, like in most other European Union countries, the protection of biodiversity in agriculture is carried out in accordance with rural development programs (Mierauskas, 2012; Mierauskas,

Copyright (C) 2017 The Authors. Published by Aleksandras Stulginskis University. This is an open-access article distributed under the terms of the Creative Commons Attribution License (CC-BY 4.0), which permits unrestricted use, distribution, and reproduction in any medium, provided the original author and source are credited. 
2014). The government support program for the period 2004-2006 provided for a range of measures, from 2007 onwards support for agriculture is divided according to the Rural Development Program for Lithuania 2007-2013. Since 2004, agrienvironment payments started to be paid in Lithuania. The concept of agri-environment has become even more important over the years as the program has evolved (Kurlavičius, 2010). The rural development policy of the EU, often referred to as the "second pillar" of the Common Agricultural Policy (CAP), seems to be integrated into the system of direct payments to farmers and agriculture market management measures (the so-called first pillar) (Kaimo ..., 2016). On February 13, 2015, the Commission officially approved the 2014-2020 Lithuanian Rural Development Program (RDP). It outlines the main priorities of Lithuania - to modernize small and medium-sized farms and improve the results of their economic activity. The goal of rural development is to improve the economic and social situation in rural areas (Kaimo ..., 2015).

The measures of the Rural Development Program are one of the ways to achieve the goals set by Lithuania regarding modernization of farms. Agri-environmental spectrum measures ensure a balanced development of the country's territory, which preserves a healthy and harmonious human habitat and natural landscape elements as well as ensures overall ecological stability. As part of the EU's rural development policy, the measure for improving agri-environmental and climatic conditions has been continuously improved.

The aim of the study is to summarize the essential differences and similarities of the agrarian environmental protection measures of the RDP for the years 2007-2013 and 2014-2020.

\section{METHODOLOGY}

The methods of the analysis of documents (EU and LR legal acts), scientific literature and synthesis of sources, graphical representation of results were used in the paper. Statistical information on the implementation of the Rural Development Program for Lithuania was obtained from the NPA (National Paying Agency under the Ministry of Agriculture of the Republic of Lithuania) database. RDP essential differences and similarities as well as value remains of the years 2007-2013 and 2014-2020 were summed up.

\section{RESULTS}

After Lithuania's accession to the EU, the Rural Development Program for the period 2004-2006 was prepared. The general objective and trends of the Lithuanian Rural Development as well as the priorities of each trend, based on the Lithuanian National Rural Development Strategy are presented in the general vision of rural development. The agrarian environmental protection measure of the RDP for 2004-2006 was one of seven.

The "Agri-environmental" measure itself consisted of 4 following schemes: the establishment of shore protective belt for surface water bodies in meadows and arable land, and erosion protection, landscaping stewardship scheme, organic farming and rare breeding schemes for livestock and poultry. If we compare this measure with the current agri-environmental and climate measure of the RDP for the period 2014-2020, we see that 3 schemes of the first measure together "went" to RDP of the years 2014-2020, and the organic farming scheme has separated and is now a separate measure.

Whether the payments have been properly absorbed can only be answered by evaluating the results achieved. As stated in the progress report of 2013 of the Lithuanian Rural Development Program for 2007-2013 prepared by the Ministry of Agriculture of the Republic of Lithuania (Lietuvos kaimo, 2014) - the most successful were the planned goals of the schemes "Landscape Stewardship" and "Organic Farming". During the period between the years 2007 and $201390 \%$ of planned holdings were based under the scheme "Landscape stewardship", and the target value for the area was $102 \%$. According to the "Organic Farming" scheme, the number of holdings and area indicators reached 63\% and 91\%, respectively.

The indicators for the schemes "Preservation of endangered Lithuanian ancient animal and domestic bird breeds" and "Environmentally sustainable fruit and vegetation system" were successfully implemented. The lowest achievement of the monitoring indicators during the period of the years 2007 and 2013 was of the scheme "Improvement of the status of water bodies "at risk", , because the target number of approved applications was only $3 \%$ achieved, and the index of underlying area was only $2.4 \%$. The report (Lietuvos kaimo..., 2014) also emphasizes that both the financial volume and the number of schemes and activities of "Agri-environmental payments" measure is very large, therefore, it contributes most to the conservation of biodiversity in the country from Axis II measures.

Nevertheless, there were also factors that negatively impacted the implementation of the scheme through the measure - too low payment rates and the fact that the area for which the compensatory payment is paid should not be less than 1 ha. As a result, people with fewer holdings could not claim support. The money received is one way or another more important than the potential benefits to the environment itself and its biodiversity. On the other hand, it is becoming more and more difficult to maintain biological prosperity across Europe - as economic activity intensifies in agrarian areas biodiversity is shrinking. According to Y.R. Hoogeveen (2001), the situation of plants and animals is gradually deteriorating, no matter how we protect them. These processes are mainly driven by the transformation of meadows into arable land, the use of pesticides or fertilizers, early mowing, depletion of wet meadows, intensive grazing, sowing of meadows with cultural grasses, or complete cessation of economic activity, resulting in the growth of meadows with shrubs and trees, as well as other factors.

The implementation of Agri-environmental activities contributes to the restoration, conservation and enhancement of biodiversity. This means the creation, restoration, maintenance of various habitats, and the promotion and maintenance of friendly farming in the most vulnerable areas. Environmental activity contributes to the implementation and continuity of measures relating to the implementation of the Water Framework Directive ... (EC) No 60/2000, Directive (EC) No 128/2009 establishing a framework for Community actions to achieve a sustainable use of pesticides and Directive (EEC) No 676/91 
on the protection of waters against pollution caused by nitrates from agricultural sources (Lietuvos ..., 2015). Water management is improved, at the same time management of fertilizers and plant protection is improved as well. At the same time, soil is protected from degradation and erosion, soil quality is improved and climate change adaptation is encouraged.

\section{Essential differences and similarities between RDP measures for the years 2007-2013 and 2014-2020 promoting agri-environmental protection}

In the Rural Development Regulation for EU member states, including Lithuania, mandatory financial liabilities for the years 2014-2020 are set. One of them is defined as follows: "At least 30\% of funds are allocated for climate change mitigation, agri-environment and organic farming, including payments to farmers farming in areas with natural or other handicaps and continuous payments for previous program periods". Financial commitments of the same amount were proposed for the period of the years between 2007 and 2013 in the Rural Development Regulation. Thus, financial liabilities and their size remain unchanged.

The RDP measure "Agri-environment payments" for the years 2007-2013 consisted of 4 schemes (Fig. 1), and the Landscape Stewardship scheme was divided into 8 other activities. The RDP measure "Agri-environment and climate" for the years 2014-2020 has been adjusted and divided into 11 schemes (Fig. 2).

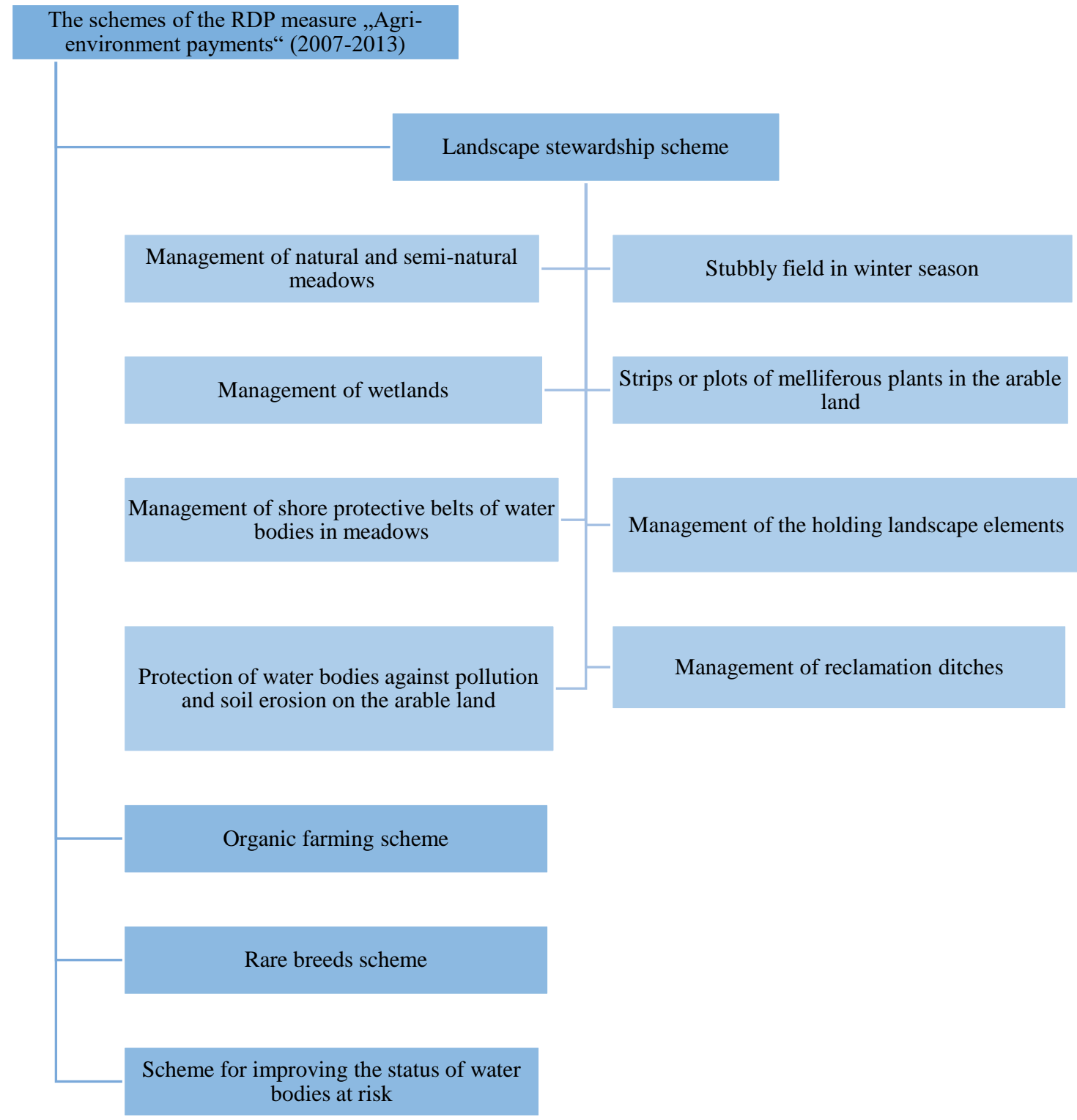

Figure 1. Trends of the measure „Agri-environment payments“ (Formed according to the data of Lithuanian village .., 2015)

The "Agri-environment payments" measure was implemented in accordance with 2 implementing regulations of the "Agri-environmental payments" measure: one implementing regulation was devoted to the following schemes: "Landscape stewardship", "Organic farming", "Improving the status of water bodies ,at risk“", and "Environmetally friendly fruits and vegetables cultivation system" and others for the implementation of the scheme "Preservation of endangered Lithuanian ancient animal and domestic bird breeds". In 2013, regulations for implementing the first measure were exchanged twice, and the second one was changed once (Lietuvos...,2014). 
When comparing the RDP measure to improve agri-environment for the years 2007-2013 and 2014-2020, we can see that there has been no previous organic farming measure in the 2014-2020 program. The above-mentioned measure was separated and somewhat modified by regulations.

The measure for preserving endangered Lithuanian ancient animal and domestic bird breeds in the new program is also more distinct - it belongs to the "Agri-environment and climate" measure, but it has completely different regulations and payment rates.

The program for improving the status of water bodies "at risk" for the period 2007-2013 has been included in the 2014-2020 program as well as in three other measures of the landscape stewardship scheme:

- $\quad$ Protection of shore protective belts of water bodies against pollution and soil erosion on the arable land;

- $\quad$ Strips or plots of melliferous plants in the arable land;

- Management of reclamation ditches.

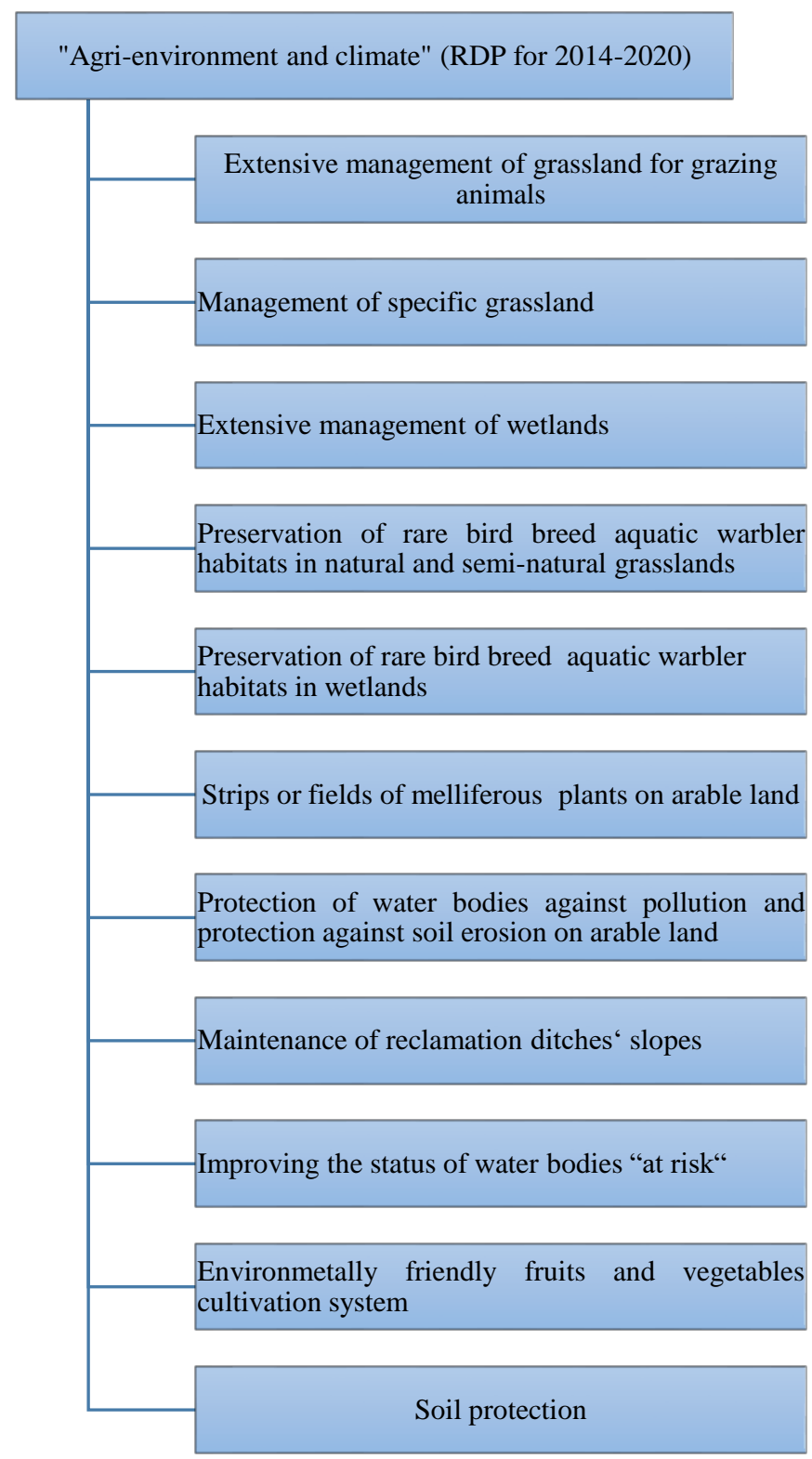

Figure 2. Activity and payment trends of the measure "Agri-environment and climate" (Formed according to the data of Lithuanian village .., 2015)

The remaining trends for the landscape stewardship scheme for 2007-2013 ("Management of natural and seminatural meadows", "Management of wetlands", " Management of shore protective belts of water bodies in meadows", "Stubby field in winter season", "Management of the landscape elements in the hedgerows") were not mentioned in the "Agri-environment and climate" measures list for 2014-2020, but if the applicants continue their remaining commitments under the "Landscape stewardsip" scheme of the Lithuanian Rural Development Program for 2007-2013 "Agrienvironment payments" program, they will be subject to the 2007-2013 implementing regulations for the RDP measure "Agri-environmental payments".

In order to make a meaningful comparison of these 4 trends from the RDP of the years 2007-2013 and 2014-2020, a table was made (Table 1), which clearly shows the similarities and differences of the trends. 
When comparing the trend - „Improvement of water bodies ,at risk“, it is possible to notice that regulations for grazing and the permitted minimum of arable land area have changed. In the period 2014-2020, the area (Table 1), which may contain $1 \mathrm{CA}$ (conventional animal) in extensive livestock farming (animals of extensive breeds are smaller, earlier mature, but these animals are more resistant to environmental factors and less demanding for feed), has been reduced. It could be argued that the reduction of the grazing area for $1 \mathrm{CA}$ was simply due to the fact that the 3 ha area was too large to be used economically. The permissible minimum area of arable land suitable for conversion to a perennial meadow or pasture was also reduced from 1 to 0.5 ha. This could have affected and reduced the required area of land to $1 \mathrm{CA}$, and simply reduced the need for farmers to turn arable land into pasture or meadow. The use of fertilizers has been somewhat modified in the program for the period 2014-2020. The use of organic fertilizers started to be unavailable for the period 2007-2013. This could have been caused by the degradation of the harmful effects of organic fertilizers. The last difference between programs is the definition of the grazing period for livestock. There was absolutely no talk about it in the regulations of 2007-2013. The RDP regulations for 2014-2020 already define the grazing period. It may be that just the average grazing period is chosen. Also, during this period, there is already a decrease in the probability of spring and autumn rainfall.

Table 1. Comparison of the RDP measures for the years 2007-2013 and 2014-2020 and the changes planned therein (made according to Lithuanian .., 2007; Kaimo plètra ... 2016)

\begin{tabular}{|c|c|c|c|}
\hline \multirow{2}{*}{$\begin{array}{l}\text { The name of the } \\
\text { RDP measure }\end{array}$} & \multirow{2}{*}{ Regulations } & \multicolumn{2}{|c|}{ Program period } \\
\hline & & $2007-2013$ & $2014-2020$ \\
\hline \multirow{6}{*}{$\begin{array}{r}\text { "Protection of } \\
\text { water bodies } \\
\text { against pollution } \\
\text { and soil erosion } \\
\text { on the arable } \\
\text { land" }\end{array}$} & Protective belt for activities & $\begin{array}{l}\text { In the } 5-10 \text { meter wide } \\
\text { protective belt }\end{array}$ & $\begin{array}{l}\text { In the 5-10 meter wide protective } \\
\text { belt }\end{array}$ \\
\hline & Fertilizers and pesticides & $\begin{array}{l}\text { It is forbidden. Only organic } \\
\text { fertilizers are allowed }\end{array}$ & $\begin{array}{l}\text { It is forbidden. Only organic } \\
\text { fertilizers are allowed }\end{array}$ \\
\hline & Livestock grazing & $\begin{array}{l}\text { Starting the process no earlier } \\
\text { than June } 15\end{array}$ & From May 1 by October 30 \\
\hline & Livestock grazing intensity & $\begin{array}{l}\text { At an intensity not exceeding } 1 \\
\text { CA/ ha }\end{array}$ & $1 \mathrm{CA} / \mathrm{ha}$ \\
\hline & $\begin{array}{l}\text { Suitable for support agricultural land } \\
\text { area }\end{array}$ & Not less than 1 ha & Not less than 0.5 ha \\
\hline & Mowing & By the water body line & Coastal protective belt \\
\hline \multirow{5}{*}{$\begin{array}{r}\text { „Improvement } \\
\text { of water bodies } \\
\text { „at-risk““ “ }\end{array}$} & Extensive livestock breeding & not more than $1 \mathrm{CA} / 3 \mathrm{ha}$ & No more than $1 \mathrm{CA} / \mathrm{ha}$ \\
\hline & $\begin{array}{l}\text { The area of arable land transformed } \\
\text { into perennial pasture or meadow }\end{array}$ & Not less than 1 ha & Not less than 0.5 ha \\
\hline & Use of fertilizers & $\begin{array}{l}\text { Do not use pesticides and } \\
\text { fertilizers }\end{array}$ & $\begin{array}{l}\text { Mineral fertilizers are forbidden. } \\
\text { Permitted only organic fertilizers }\end{array}$ \\
\hline & Grass sowing/cutting/removal & Exact terms are specified & Exact terms are specified \\
\hline & Livestock grazing period & Not specified & From May 1 until October 30 \\
\hline \multirow{7}{*}{$\begin{array}{c}\text { „Strips or plots } \\
\text { of melliferous } \\
\text { plants in the } \\
\text { arable land “ }\end{array}$} & Total declared area of arable land & $\begin{array}{l}\text { Not less than } 2 \text { ha (only } \\
\text { participating in this activity) }\end{array}$ & At least 5 ha \\
\hline & $\begin{array}{l}\text { Homogeneous area of the plot or } \\
\text { strip }\end{array}$ & $\begin{array}{l}\text { Not more than } 0.5 \text { ha in the plot } \\
\text { of } 10 \text { ha }\end{array}$ & $\begin{array}{l}\text { Not less than } 0.5 \text { ha in the plot of } \\
5 \text { ha }\end{array}$ \\
\hline & Quantity of plant species & At least 3 species & At least 3 species \\
\hline & Width of mixture belts & Not less than $6 \mathrm{~m}$ & Not less than $6 \mathrm{~m}$ \\
\hline & $\begin{array}{l}\text { Minimum / maximum amount of one } \\
\text { species of melliferous plants }\end{array}$ & Not more than $70 \%$ & Not more than $70 \%$ \\
\hline & Livestock grazing & From September 15 & $\begin{array}{l}\text { The area is cut, animals are not } \\
\text { allowed }\end{array}$ \\
\hline & Fertilizers & $\begin{array}{l}\text { Use of pesticides, fertilizers, } \\
\text { lime is prohibited }\end{array}$ & $\begin{array}{l}\text { All kinds of fertilizers are } \\
\text { forbidden }\end{array}$ \\
\hline \multirow{4}{*}{$\begin{array}{r}\text { "Management of } \\
\text { reclamation } \\
\text { ditches" }\end{array}$} & Mowing period & July 15 th - September 30 & Not specified \\
\hline & Shrubbery & By September 30 & By September 30 \\
\hline & 1 meter wide protective belt & No restrictions & $\begin{array}{l}\text { Plowing is prohibited, use of any } \\
\text { fertilizers is prohibited }\end{array}$ \\
\hline & Shrub and grass removal & By September 30 & By September 30 \\
\hline
\end{tabular}

Another trend of the RDP, which from 2007-2013 program was launched in 2014-2020 program - "Protection of water bodies against pollution and soil erosion on arable land". Looking at the comparisons between these two trends, one can see that there are very few differences. One of the differences between 2007-2013 and 2014-2020 RDP measure to improve agri-environmental protection in the trend "Protection of water bodies from pollution and soil erosion on arable land" - is a double reduction in the size of the utility area that would meet the minimum threshold. The area of agricultural land suitable for support is reduced by half - from 1 ha to 0.5 ha. This could have been due to the fact that near water bodies, most people have narrow sections of the plot of land, and if the activity can be carried out only 5-10 meters from the water body - often that part of the plot is less than 1 ha. Another change between programs is the concretization of grazing period. In 2007-2013, it was allowed to graze animals from June 15 and in the program of 2014-2020, it is already allowed to graze animals from May 1 but only until October 30. It may be that the beginning of the grazing of animals was predisposed to advance due to the fact that the grazing of animals in the water protective belt does not cause significant pollution. 
Another agri-environmental trend that has survived from RDP measure for 2007-2013 to this day - "Strips or plots of melliferous plants in the arable land". In this measure 3 changes from the period 2007-2013 - the total declared area, the grazing of animals, the permissible size of the area of the plot or the belt, the use of fertilizers (Table 1).

The possible minimum total declared area has changed very clearly - the ratio of the area of the field or homogeneous strip to 1 hectare has also changed. This could have been due to the practice of the RDP of 2007-2013 period, during which it was supposed to see that in 10 ha the strip of 0.5 ha area is too small to achieve the efficiency of this trend. According to the RDP for 2014-2020 the use of all fertilizers (also organic) was prohibited in the strip of melliferous plants, which resulted in the prohibition of livestock grazing. This could have been banned due to the potentially negative reaction of melliferous plants to organic fertilizers.

The fourth, and last, trend, which has remained since RDP for 2007-2013 - "Management of reclamation ditches". This direction has been and is subject to the least restrictions. Precise mowing period in the program of 2014-2020 has not been set but the bush harvest time has been set. However, the last day of mowing and harvesting in both programs is September 30. The deadline is set simply on the general order. The ban on fertilizer use was not discussed in the program of 2007-2013, but their application is now banned. This could have led to the unknowingness of the people who are carrying out this trend - fertilizers are often used carelessly and do not comply with environmental requirements.

Comparing four similar RDP trends for improving agri-environmental protection, it can be stated that the RDP measure for 2014-2020 is characterized by more favorable regulations for stakeholders and, at the same time, a more clear set of terms. This is probably caused by the failures of the RDP for the years 2007-2013. In that year, a large part of the applications was rejected solely because applicants who participated in the program did not even have a minimum reservation on the required area - it should have been 1 ha. Besides, in the course of the RDP for 2007-2013, it has already been started to talk about reducing these requirements.

\section{Efficiency of agri-environmental measures}

Countrywide, measures in the rural development program are becoming more and more difficult to implement due to increasing emigration. Those remaining to farm are often discouraged from the development of rural development programs by high requirements and commitments made for 5 years. These are the main reasons that hinder at the same time and the development of the agri-environment in the country. One more negative factor in the implementation of RDP measures (and also the agri-environment) is the decreasing amount of agricultural production. This is an important indicator, as farmers tend to choose a large harvest rather than an agri-environmental or other measure.

In evaluating the positive and negative aspects of the implementation of the RDP, it should be noted that the agri-environmental measure preserves natural flora and fauna, fosters the old countryside and creates a new, more beautiful landscape. It should be noted that the regulations of the measure are relatively simple and, therefore, are usually implemented successfully (no penalties are imposed on farmers). The state control over the implementation of land use and RDP measures can be positively assessed, which is explicitly included in the RDP program and its rules for 2014 2020. Participation of state and municipalities in RDP measures is active and effective. Positive responses can also be made to the legal status and regulation of a specific RDP measure. Different requirements are applied to participants of previous years and beyond. Requirements for newcomers are higher and payments are lower.

When assessing agri-environmental measures in the eyes of the farmer, the specificity of the rates of payments is often missed. They are usually replaced every year. In this case, farmers can not plan their income and expenses. There is also a positive aspect here - the NPA service pays out benefits in a timely manner (several years ago there were quite frequent delays in payments). NPA staff carefully scrutinize fields and documents to be filled in.

Payment amounts are not well balanced according to different programs. Due to insufficient financing, farmers will not be able to carry out measures and abandon harvest, besides, not all measures are suitable for all farmers ("Extensive wetland management", "Management of water bodies “at risk”", etc.).

In order to increase the number of people interested in implementing the previously analyzed 4 agrienvironmental trends, the introduction of strict deadlines should be abolished, which is excessive control that promotes the inappropriate distribution of energy by the beneficiaries. Individuals who are interested in agri-environmental measures should be concerned not only with the financial side of this measure, but also about aesthetic value and social well-being, which would result in a better overall impact of the program and a spontaneous effect. In the agrienvironmental trend, the amount of livestock in the defined area should also not be an indicator for assessing the quality of agri-environmental protection. In particular, in the case where organic fertilizers are permitted in the declared area. Farmers who are skilled in their work will never be interested in having their animals consume less feed than they need.

The implementation of agri-environment encourages the emphasis on environmental protection, as well as the mitigation and, at the same time, adaptation to climate change. Farmers who undertake agri-environmental commitments combine their farming activities without detriment to the landscape, natural resources and soil..

\section{CONCLUSIONS AND SUGGESTIONS}

1 After analyzing the RDP measure "Agri-environment payments" for the period 2007-2013 and the RDP measure "Agri-environment and climate" for the period 2014-2020, it has been established that both measures are linked by four equal trends, the efficiency of which is improved by adjusting the rules.

2 Comparing the 4 RDP agri-environmental measures of the 2007-2013 and 2014-2020 that have the same impact, the biggest differences are evident when comparing terms for mowing, shrubbery, livestock grazing, etc. The RDP 
agrarian environmental protection measure for the period 2014-2020 features as a more favorable rule for the interested parties and as a set of clearer terms. All other indicators were adjusted marginally.

3 The key difference of the RDP "Agri-environment and climate" for the period 2014-2020 is the elimination of organic farming. The new measure is immediately divided into areas of activity that are 12, while the old one has 4 trends, of which one (Landscape stewardship) has been divided into 8 areas of activity. The new measure did not cover the previously existing areas of landscape management, the "Management of landscape elements in the holding", "'Stubbly field in winter season", "Management of natural and semi-natural meadows", "Management of wetlands", " Management of shore protective belts of water bodies in meadows ". The aforementioned trend can be continued by farmers only if they carry out the old commitments and continue to do so.

4 The factors of the RDP measure "Agri-environment payments" for the period 2007-2013, which are of low interest, are the small amount of payments and the required 1 ha of utilities' area under which the payment is paid. This has led to a smaller number of farmers who would like to implement the measure. The problem of low payments has remained until today. The greatest benefit of the measure is the improved biodiversity of the country. The main driving force of the measure is financial support.

5 The development of rural development programs is often discouraged by high requirements and commitments made over 5 years. Reducing strict and often unnecessary deadlines, training on the aesthetic and social value of the measure "Agri-environment and climate" would increase the synergies that would help farmers to better understand the benefits (not just financial) of the measure and more critically evaluate their environmental activities.

\section{REFERENCES}

1. Cooper, J.C. 2009. Economic Aspects of Revenue-Based Commodity Support. Economic Research Report 55838, United States Department of Agriculture, Economic Research Service.

2. Hoogeveen, Y.R., Petersen, J.E., Gabrielsen, P. 2001. Agriculture and Biodiversity in Europe. Background report to the highlevel European conference on Agriculture and Biodiversity. 5-7 June, Paris. STRA-CO/AGRI 17. Council of Europe/UNEP.

3. Kaimo plètra 2014-2020 m. 2016. [Rural development 2014-2020]. Available at < http://ec.europa.eu/agriculture/ruraldevelopment-2014-2020/index_lt.htm> (accessed on 23/08/2016). [In Lithuaniana]

4. Kaimo plètros perspektyvos 2014-2020 metais. 2013. Kaimo plètros dempartamentas Available at http://www.esparama.lt/es parama pletra/failai/fm/failai/ES paramos ateitis/Komisija 2014 2020/20130927medziaga/Kaimo_pletros_perspektyvos.pdf (Accessed on 20/08/2016).

5. Kurlavičius, P. 2010. Agrarinė aplinkosauga. Lietuvos ornitologų draugija. Baltijos aplinkos forumas. 180 p. [In Lithuaniana]

6. Lietuvos kaimo pletros 2007-2013 m. programa. 2015. [Rural Development Programme for Lithuania 2007 - 2013]. Available at: http://www.nma.lt/ataskaita/admin-programos/lietuvos-kaimo-pletros-2007-2013-m-programa/.(Accessed on 07/01/2017). [In Lithuaniana]

7. Lietuvos kaimo plètros 2007-2013 metų programos 2013 metų pažangos ataskaita. 2014. [Progress Evaluation of the Lithuanian Rural Development Programme 2007-2013 in the Year 2013]. Available at: https://zum.lrv.lt/uploads/zum/documents/files/LT_versija/Veiklos_sritys/Kaimo_pletra/Programos_stebesena_ir_vertinimas/Ata skaitos/PP2013pazangosataskaita20140626GALUTINE.pdf (Accessed on 10/09/2017). [In Lithuaniana]

8. Lietuvos kaimo plètros 2007-2013 metų programos priemonès „Agrarinès aplinkosaugos išmokos“ programų „Kraštovaizdžio tvarkymas“, „Ekologinis ūkininkavimas“ ir „Rizikos“ vandens telkinių būklès gerinimas“ igyvendinimo taisykles, patvirtintos Lietuvos Respublikos žemès ūkio ministro 2007 m. balandžio 6 d. ịsakymu Nr. 3D-152 „Dèl Lietuvos kaimo plètros 2007-2013 metų programos priemonès „Agrarinès aplinkosaugos išmokos“ programų „Kraštovaizdžio tvarkymas“, „Ekologinis ūkininkavimas“ ir „Rizikos“ vandens telkinių būklès gerinimas“ igyvendinimo taisyklių patvirtinimo. 2007. Valstybès žinios, Nr. 41-1561; 2011, Nr. Nr. 34-1631. [In Lithuaniana]

9. Mierauskas, P. 2012. Gamtosaugos programų igyvendinimo žemės ūkyje socialiniai ekonominiai aspektai. Socialiniu moksly studijos. Vol.4, No. 4. P. 16. [In Lithuaniana]

10. Mierauskas, P. 2014. Biologinei ịvairovei palankių ūkininkų dalyvavimo lietuvos saugomų teritorijų valdyme vertinimas. Socialiniu mokslu studijos. Vol. 6, No. 2, pp 421-439. [In Lithuaniana]

11. Mouysset, L., Doyen, L., Jiguet, F., Allaire, G., Leger, F. 2011. Bio economic modeling for a sustainable management of biodiversity in agricultural lands. Ecological Economics. Vol. 70, No. 4. pp. 617-626. https://doi.org/10.1016/j.ecolecon.2010.12.006

12. Whittingham, M. J. 2007. Will agri-environment schemes deliver substantial biodiversity gain, and if not why not? Journal of Applied Ecology, Vol. 44, pp. 1-5. https://doi.org/10.1111/j.1365-2664.2006.01263.x 